\section{Pollination Strategies to Improve Fruit Set in Orchards of 'Manzanillo' Olive in a Nontraditional Producing Country, Mexico}

\author{
Alberto Sánchez-Estrada ${ }^{1}$ and Julián Cuevas ${ }^{2,3}$
}

ADDITIONAL INDEX WORDs. fertilization, Olea europaea, pollen germination, pollen tube growth, self-incompatibility

\begin{abstract}
SUMMARY. In countries new to producing 'Manzanillo' olive trees (Olea europaea), free cross-pollination is often insufficient to obtain high levels of fruit set. An appropriate pollination design is therefore essential to ensure a timely, abundant, and compatible pollen supply. With a view to determining whether a pollination deficit exists in a nontraditional olive area such as the northern Mexico, pollination experiments were carried out in two consecutive seasons in both a monovarietal and a multivarietal Manzanillo orchard, where Sevillano, Barouni, Picual, Pendolino, Mission, Nevadillo, and Frantoio trees were growing nearby. The pollination treatments were self-, open, and cross-pollination with 'Barouni' and 'Sevillano' pollen, the latter only in the multivarietal orchard. The results confirmed the full self-incompatible condition of 'Manzanillo'. Open-pollination did not improve fruit set in the monovarietal orchard, but it did so significantly in the multivarietal plot, where fruit set levels under open-pollination matched those of cross-pollination. Lower pollen adhesion, as well as occasional decreased germination, and reduced and delayed pollen tube growth were observed under self-pollination, highlighting self-incompatibility reactions. The reduction in fertilization rates led to low fruit set under self-pollination. Positive effects of open- and cross-pollination treatments were also noted on fruit weight (despite higher crop loads) and pulp-topit ratios. A strategic plantation design, including appropriate pollinizers in the right number and position, is therefore suggested for increasing 'Manzanillo' fruit quality and yield in Mexico. Both 'Barouni' and 'Sevillano' served as efficient pollinizers for 'Manzanillo', although we recommend 'Barouni' as a more efficient because the bloom periods of them matched that of 'Manzanillo'
\end{abstract}

$\mathrm{O}$ live is an andromonoecious species-that is, each olive tree forms perfect hermaphrodite flowers and staminate flowers, a result of pistil abortion. Olive also exhibits strong alternate bearing, with a high flowering season ("on year") followed by a year of light flowering and yield ("off years") due to inhibition of flower induction caused by excessive previous crop

Received for publication 29 Oct. 2018. Accepted for publication 21 Dec. 2018.

Published online 7 May 2019.

${ }^{1}$ Coordinación de Alimentos de Origen Vegetal, Centro de Investigación en Alimentación y Desarrollo, A.C. Km 0.6 Carr. A La Victoria, C.P. 8300, Hermosillo, Sonora, Mexico, Department of Agronomy, ceiA3, 04120 Almería, Campus de Excelencia Internacional Agroalimentaria (ceiA3), University of Almería, La Cañada de San Urbano, s/n 04120, Almería, Spain

${ }^{2}$ Department of Agronomy, ceiA3, 04120 Almería, Campus de Excelencia Internacional Agroalimentaria (ceiA3), University of Almería, La Cañada de San Urbano, s/n 04120, Almería, Spain

${ }^{3}$ Corresponding author. E-mail: jcuevas@ual.es.

This is an open access article distributed under the CC BY-NC-ND license (https://creativecommons.org/ licenses/by-nc-nd/4.0/).

https://doi.org/10.21273/HORTTECH04231-18 load. Olive orchards in Spain and other Mediterranean countries are commonly monovarietal, despite the partial self-incompatibility of most olive varieties. This is possible because open, wind pollination is often sufficient to obtain adequate yield, given the extraordinary varietal richness found in most traditional olive regions, where a mixture of varieties growing nearby is common (Pinillos and Cuevas, 2009). The situation is quite different in North America. In Mexico and the United States, olive orchards often are planted in isolated areas where the amount of crosspollen available is limited (Shemer et al., 2014). This pollination deficit frequently reduces fruit set and yield in olives (Ayerza and Coates, 2004; Navarro-Ainza and López-Carvajal, 2013; Sibbett et al., 1992). Therefore, to ensure a high yield, orchard designs including pollinizers in the correct proportion and position are required in these nontraditional olive countries. Artificial pollination is also an alternative (Sibbett et al., 1992).

If a pollination design is required, the chosen pollinizer must meet certain requirements. It must be intercompatible with the main variety, bloom at the same time, and be regular (i.e., not an alternate bearer). On a secondary level, given its main function as pollen donor, it is also convenient to select high-yielding pollinizers of high commercial value and the same purpose (table or oil) with similar crop requirements and vigor (Cuevas et al., 2001).

'Manzanillo' is the most important table olive in the world (Rejano et al., 2010). Unfortunately, 'Manzanillo' yields are not always optimal. Contradictory results regarding its degree of compatibility can be found in the literature. Some authors have reported 'Manzanillo' to be highly self-incompatible (SI) (Androulakis and Loupassaki, 1990; Cuevas and Polito, 1997; Griggs et al., 1975), whereas other authors label it as only partially SI, not expressing complete rejection of self-pollen but preferring cross-pollen for fertilization and hence increasing fruit set and yield under cross pollination (Dimassi et al., 1999; Lavee et al., 2002; Wu et al., 2002).

To check 'Manzanillo' behavior and its pollination requirements in a nontraditional olive country, such as Mexico, we designed different pollination experiments with three main aims. First, to determine whether a pollination deficit exists in monovarietal Manzanillo orchards, establishing the level of selfincompatibility exhibited. Second, to compare 'Manzanillo' response to

\begin{tabular}{llll}
\hline $\begin{array}{l}\text { Units } \\
\text { To convert U.S. to SI, } \\
\text { multiply by }\end{array}$ & U.S. unit & SI unit & $\begin{array}{l}\text { To convert SI to U.S., } \\
\text { multiply by }\end{array}$ \\
\hline 0.3048 & $\mathrm{ft}$ & $\mathrm{m}$ & 3.2808 \\
25.4 & inch(es) & $\mathrm{mm}$ & 0.0394 \\
1.6093 & $\mathrm{mile}(\mathrm{s})$ & $\mathrm{km}$ & 0.6214 \\
28.3495 & $\mathrm{Oz}$ & $\mathrm{g}$ & 0.0353 \\
28,350 & $\mathrm{OZ}$ & $\mathrm{mg}$ & $3.5274 \times 10^{-5}$ \\
$\left({ }^{\circ} \mathrm{F}-32\right) \div 1.8$ & ${ }^{\circ} \mathrm{F}$ & ${ }^{\circ} \mathrm{C}$ & $\left({ }^{\circ} \mathrm{C} \times 1.8\right)+32$
\end{tabular}


open-pollination in monovarietal vs. multivarietal orchards of this genotype. The third objective was to select a good pollinizer for 'Manzanillo', comparing the performance of 'Sevillano' and 'Barouni' as pollen donors because these varieties are commonly used in Mexico and the United States for this purpose.

\section{Materials and methods}

Plant material and orchard LOCATION. Pollination experiments were carried out in 2016 and 2017 in two 'Manzanillo' orchards. One of the orchards was a monovarietal plot, and the other was a multivarietal orchard, having Manzanillo as the principal variety and Pendolino, Frantoio, Barouni, Sevillano, Picual, and Nevadillo as potential pollinizers. The orchards were located $3 \mathrm{~km}$ apart, in northern Mexico (lat. 30 50'001 ${ }^{\prime \prime} \mathrm{N}$, long. $112^{\circ} 54^{\prime} 026^{\prime \prime} \mathrm{W}$ ) at $200 \mathrm{~m}$ elevation. According to Ruíz-Corral et al. (2005), the climate of the area is of the Sonoran desert type with $150 \mathrm{~mm}$ precipitation per year, mostly during summer and winter. Average mean daily temperatures range from 4 to $25{ }^{\circ} \mathrm{C}$ in winter and 26 to $45^{\circ} \mathrm{C}$ in summer. Single-trunk 15-year-old olive trees, vase-trained at a planting distance of $8 \times 10 \mathrm{~m}$, were used for both experiments. Orchard management includes downstream irrigation and weed control by tillage in both cases.

EXPERIMENTAL DESIGN AND TREATMENTS. The experiment followed a nested design where pollination treatments were placed inside the orchard type (monovarietal vs. multivarietal). Pollination treatments were self- (SP), open (OP), and hand crosspollination (CP) using 'Barouni' fresh pollen $(\mathrm{XB})$ harvested from nearby trees following procedures described in Cuevas and Pinillos (2006). A second CP treatment was implemented in the multivarietal orchard using 'Sevillano' (XS) pollen purchased from the private company Bells of Desert (Corning, CA). Mother (pollen recipient) trees acted as replication, each receiving all pollination treatments. Four homogenous highflowering (“on”) 'Manzanillo' trees were selected in each orchard. Eight reproductive shoots per tree and pollination treatment functioned as subsamples within each replication. These shoots were located at head height around the canopy. The number of panicles per shoot was adjusted by hand to 14 panicles to avoid flowering load effects on fruit setting.

SP was achieved by covering the shoots before flowering with handmade bags of tissue paper. SP deposition was favored by frequent shaking of the shoots. Bags were not removed until the flowering season had ended. OP shoots were left uncovered and received free winddispersed pollen from nearby trees. 'Pendolino', 'Frantoio', 'Sevillano', 'Picual', 'Nevadillo' and, in a higher proportion, 'Barouni' trees were planted as pollinizers in one row of every four of 'Manzanillo' (20\% of pollinizers) in the multivarietal orchard. No potential pollinizers were present in the monovarietal orchard. CP treatments were achieved by applying either 'Barouni' fresh pollen or purchased 'Sevillano' pollen to the stigmas of 'Manzanillo' flowers using a fine paintbrush. Pollen viability was ascertained before use by the fluorochromatic staining test proposed by Heslop-Harrison and HeslopHarrison (1970), slightly modified by Pinillos and Cuevas (2008). Pollen viability in 2016 was $68.9 \%, 84.8 \%$, and $70.1 \%$ for 'Manzanillo', 'Barouni', and 'Sevillano', respectively, and $82.9 \%, 78.3 \%$, and $73.7 \%$, respectively, in 2017. Hand CP started at the beginning of bloom and was repeated every other day, twice more. Cross-pollinated flowers remained bagged before and after hand pollinations and until blooming ceased.

FRUIT SET, FRUIT WEIGHT AND SELF-INCOMPATIBILITY INDEX. Fruit set was calculated on the tagged shoots as the number of fruit per panicle $45 \mathrm{~d}$ after pollination (DAP), when fruitlet abscission had ended, and fruit population was firmly established (Rapoport and Rallo, 1991). Shotberries were not counted. Selfincompatibility index (ISI) was calculated as the ratio between fruit set under self- and open or cross pollination (Zapata and Arroyo, 1978). ISI usually varies between 1 (full selfcompatibility) and 0 (strong selfincompatibility). Near fruit maturity in mid-August, all fruit present on the tagged shoots were harvested and weighed in the laboratory, where the stones of the drupes were removed from the pulp and weighed to obtain pulp-to-pit ratio.
Flower number per panicle, flower fertility, and quality by flower dry weight were estimated and compared by analysis of variance (ANOVA) in 2016. Fruit set, selfincompatibility index, and fruit and pit weight were compared over both seasons by ANOVA. Tukey's Studentized range test was used for the separation of the means. Infostat software (version 2017e; University of Córdoba, Córdoba, Argentina) was used for these analyses.

Analyses of pollen-pistil InTERACTION. Pollen-pistil interaction was analyzed on samples of self-, open-, and cross-pollinated flowers using 'Barouni' or 'Sevillano' pollen collected 2, 4, 6, and 8 DAP (20 flowers per pollination treatment and sampling date; 80 flowers per treatment in total). Pollination was always performed on anthesis. Anthesis date was ensured by removing open flowers on a given day, and closed flowers the next day, so all remaining flowers opened between one given day and the next. Pollination treatments were applied as already described. Sampled flowers were excised from the shoots and fixed in FAE (formalin to glacial acetic acid to $70 \%$ ethanol in a $1: 2: 17$ ratio by volume) until observations, processed as explained in Cuevas et al. (1994), and stained using aniline blue for observations under fluorescence microscopy (Martin, 1958) in a epifluorescence microscope (Labophot; Nikon, Tokyo, Japan).

Pollen adhesion, germination, pollen tube growth, fertilization occurrence, and date were determined in each flower and the results averaged for each pollination treatment and date. This analysis was carried out in the multivarietal orchard where all pollination treatments were represented. The number of pollen grains adhered to the stigmas of the flowers was estimated by counting under a microscope the number of pollen grains in three small areas of the stigma defined by the field observed by the microscope objective lens $(\times 40)$, and then the total number per flower was calculated taking into account the common size of the stigma of 'Manzanillo' (Griggs et al., 1975). Pollen germination was expressed as the ratio between pollen grains adhered and those germinated forming a pollen tube and penetrating 
the stigma. According to the number of tubes observed, pollen tube growth in the style was classified as null (no tubes), scarce (1-4 tubes), moderate (5-25 tubes), or massive (more than 25 tubes) (Supplemental Fig. 1). An ovule was considered fertilized if a pollen tube was present at the micropyle or if the ovule (Supplemental Fig. 2) had become a developing seed; i.e., if one ovule had grown more than three times its initial size and the other three ovules of the ovary were senescent (Cuevas et al., 1994; Seifi et al., 2011).

Pollen adhesion, germination, and tube growth levels were compared by analyses of variance. Tukey's Studentized range test was used for the separation of the means. Pollen germination percentages were arcsine transformed previously. Chi-square analyses were performed for the comparison of fertilization levels. Infostat version $2017 \mathrm{e}$ software was used for the analyses.

BLOOMING PERIODS AND OVERLAP With 'Manzanillo' Flowering. Blooming periods were determined following the procedure described by Alcalá and Barranco (1992) on five high flowering ("on") trees of 'Manzanillo', 'Barouni', and 'Sevillano' growing in the multivarietal orchard. The beginning of bloom (as the first day open flowers appeared), end of bloom (as the last day open flowers were noted), beginning of full bloom (as the first day flowering stage was the most common), and end of full bloom (as the last day when flowering stage was the most common) were ascertained in 2016-17 to determine blooming overlaps between 'Manzanillo' and its potential pollinizers 'Barouni' and 'Sevillano'. Full bloom date for each variety was established as the central day between the beginning and the end of full bloom.

\section{Results}

Flowering level and QUALITY. On a hedonic scale ranging from 0 (no flowering) to 10 (very high level of flowering), experimental 'Manzanillo' trees averaged a flowering level of 9.0 and 8.3 in 2016 and 2017 seasons, respectively, in the monovarietal orchard compared with 9.6 in 2016 and 8.6 in 2017 in the multivarietal orchard. The panicles of 'Manzanillo' in the monovarietal plot had 12.7 flowers on average, whereas the panicles of the trees growing in the multivarietal plot

Table 1. Flower quality and fertility in 'Manzanillo' olive trees of monovarietal and multivarietal orchards (season 2016). Analysis of variance in a completely randomized design. Four replicates (trees) per orchard, 20 panicles per tree as subsample.

\begin{tabular}{lcccc}
\hline Orchard type & $\begin{array}{c}\text { Flowers } \\
(\text { no./panicle) }\end{array}$ & $\begin{array}{c}\text { Fertile } \\
\text { panicles }(\%)^{\mathrm{z}}\end{array}$ & $\begin{array}{c}\text { Flower dry } \\
\text { wt }(\mathbf{m g})^{\mathrm{y}}\end{array}$ & $\begin{array}{c}\text { Hermaphrodite } \\
\text { flowers (\%) }^{\mathrm{m}}\end{array}$ \\
\hline Monovarietal & $12.74 \mathrm{a}^{\mathrm{x}}$ & $85.0 \mathrm{a}$ & $2.66 \mathrm{~b}$ & $19.07 \mathrm{~b}$ \\
Multivarietal & $9.74 \mathrm{~b}$ & $88.7 \mathrm{a}$ & $3.48 \mathrm{a}$ & $26.28 \mathrm{a}$ \\
\hline
\end{tabular}

${ }^{\mathrm{z}}$ Percentages were arcsine transformed before statistical analysis.

${ }^{\mathrm{y}} \mathrm{l} \mathrm{mg}=3.5274 \times 10^{-5} \mathrm{oz}$.

${ }^{x}$ Values followed by the same letter in each column are not significantly different at $P \leq 0.05$ using Tukey's Studentized range test.

Table 2. Analyses of variance of fruit set and index of self-incompatibility (ISI) in two 'Manzanillo' olive orchards (monovarietal and multivarietal) in response to pollination treatments in seasons 2016 and 2017. Nested design with orchard type as the first factor and pollination treatment as the second factor. Four trees as replicates in each treatment.

\begin{tabular}{|c|c|c|c|c|c|}
\hline \multirow[b]{2}{*}{ Orchard type } & \multirow{2}{*}{$\begin{array}{l}\text { Pollination } \\
\text { treatment }^{\mathrm{z}}\end{array}$} & \multicolumn{2}{|c|}{2016} & \multicolumn{2}{|c|}{2017} \\
\hline & & Fruit set & ISI $^{\mathbf{y}}$ & Fruit set & ISI \\
\hline \multirow[t]{3}{*}{ Monovarietal } & SP & $0.02 b^{x}$ & - & $0.02 \mathrm{~b}$ & - \\
\hline & OP & $0.03 \mathrm{~b}$ & $0.62 \mathrm{a}$ & $0.07 \mathrm{~b}$ & $0.26 \mathrm{a}$ \\
\hline & $\mathrm{XB}$ & $0.11 \mathrm{a}$ & $0.18 \mathrm{~b}$ & $0.16 \mathrm{a}$ & $0.13 \mathrm{a}$ \\
\hline \multirow[t]{4}{*}{ Multivarietal } & SP & $0.01 \mathrm{~b}$ & - & $0.02 \mathrm{c}$ & - \\
\hline & OP & $0.21 \mathrm{a}$ & $0.03 \mathrm{a}$ & $0.15 \mathrm{a}$ & $0.12 \mathrm{a}$ \\
\hline & $\mathrm{XB}$ & $0.18 \mathrm{a}$ & $0.04 \mathrm{a}$ & $0.11 \mathrm{~b}$ & $0.22 \mathrm{a}$ \\
\hline & XS & $0.18 \mathrm{a}$ & $0.04 \mathrm{a}$ & $0.07 \mathrm{bc}$ & $0.33 \mathrm{a}$ \\
\hline
\end{tabular}

${ }^{\mathrm{z}} \mathrm{SP}=$ self-pollination; $\mathrm{OP}=$ open-pollination; $\mathrm{XB}=$ cross-pollination with 'Barouni' pollen; $\mathrm{XS}=$ cross pollination with 'Sevillano' pollen.

${ }^{\mathrm{y}} \mathrm{ISI}=\mathrm{SP}$ fruit set $/ \mathrm{OP}$ or $(\mathrm{XB}$ or XS) fruit set.

${ }^{x}$ Values followed by the same letter in each column are not significantly different at $P \leq 0.05$ using Tukey's Studentized range test.

Table 3. Analyses of variance of fruit weight at harvest and its components in monovarietal and multivarietal 'Manzanillo' olive orchards in response to pollination treatments in season 2016. Nested design with orchard type as the first factor and pollination treatment as the second factor. Four trees as replicates in each treatment.

\begin{tabular}{lccccc}
\hline $\begin{array}{l}\text { Orchard } \\
\text { type }\end{array}$ & $\begin{array}{c}\text { Pollination } \\
\text { treatment }^{\mathrm{z}}\end{array}$ & ${\text { Fruit wt }(\mathbf{g})^{\mathrm{y}}}^{\text {Pulp wt }(\mathrm{g})}$ & Pit wt (g) & $\begin{array}{c}\text { Pulp to } \\
\text { pit (ratio) }\end{array}$ \\
\hline Monovarietal & SP & $3.29 \mathrm{a}^{\mathrm{x}}$ & $2.61 \mathrm{~b}$ & $0.62 \mathrm{a}$ & $4.20 \mathrm{~b}$ \\
& OP & $3.51 \mathrm{a}$ & $2.94 \mathrm{ab}$ & $0.61 \mathrm{a}$ & $4.82 \mathrm{a}$ \\
Multivarietal & XB & $3.76 \mathrm{a}$ & $3.15 \mathrm{a}$ & $0.65 \mathrm{a}$ & $4.85 \mathrm{a}$ \\
& SP & $3.36 \mathrm{a}$ & $2.47 \mathrm{~b}$ & $0.60 \mathrm{a}$ & $4.11 \mathrm{c}$ \\
& OP & $3.62 \mathrm{a}$ & $3.02 \mathrm{a}$ & $0.63 \mathrm{a}$ & $4.79 \mathrm{~b}$ \\
& XB & $4.01 \mathrm{a}$ & $3.40 \mathrm{a}$ & $0.64 \mathrm{a}$ & $5.31 \mathrm{a}$ \\
& XS & $3.22 \mathrm{a}$ & $2.71 \mathrm{ab}$ & $0.59 \mathrm{a}$ & $4.60 \mathrm{~b}$ \\
\hline
\end{tabular}

${ }^{\mathrm{z}} \mathrm{SP}=$ self-pollination; $\mathrm{OP}=$ open-pollination; $\mathrm{XB}=$ cross-pollination with 'Barouni' pollen; $\mathrm{XS}=$ cross-pollination with 'Sevillano' pollen.

${ }^{\mathrm{y}} \mathrm{lg}=0.0353 \mathrm{oz}$.

Values followed by the same letter in each column are not significantly different at $P \leq 0.05$ using Tukey's Studentized range test.

formed only 9.7 flowers. Although fewer flowers were formed, and perhaps because of this, the percentage of fertile hermaphrodite flowers and of panicles bearing at least one hermaphrodite flower, and hence with setting potential, were, on the contrary, higher in the multivarietal plot. Flowers were also significantly heavier in the multivarietal plot (Table 1).
A different response to the pollination treatments was observed at final fruit set depending on the orchard design. In the monovarietal orchard, SP and OP produced low fruit set in both 2016 and 2017 (Table 2). The most favorable treatment in this orchard was $\mathrm{XB}$, which significantly increased fruit set in both seasons with respect to SP and OP 
(Table 2). In the multivarietal orchard, OP performed slightly better than $\mathrm{CP}$ treatments (XB and $\mathrm{XS})$ in both years. The differences were small and not significant in 2016, but larger and significant with respect to XS in 2017. In sum, OP and both CP treatments produced significantly higher fruit set than SP in 2016. In 2017, however, 'Sevillano' pollen did not increase fruit set significantly (Table 2 ). As a result, ISI values were close to zero in 2016 and slightly higher in 2017, when self-incompatibility response was attenuated.

An additional positive effect of $\mathrm{CP}$ was measured in pulp weight and then in pulp-to-pit ratio (Tables 3 and 4). This effect was observed in both orchards and seasons, although it should be noted that in these parameters (especially in pulp-to-pit ratio), OP results matched or were close to those of $\mathrm{CP}$, even in the monovarietal orchard.

Pollen-Pistil interaction. The analyses of pollen-pistil interaction showed differences in pollen adhesion among treatments in both years (2016 and 2017) (Fig. 1A and B). OP and SP flowers had about 2700 pollen grains adhered to their stigmas in 2016 and about 700 in 2017 at 8 DAP, a high amount, but still significantly lower than the number of pollen grains adhered to hand $\mathrm{CP}$ flowers (Fig. IA and B). The number of pollen grains adhered to CP flowers was higher than the number of grains found in SP and OP flowers on all sampling dates. Older flowers presented more pollen than young ones, suggesting extended stigma receptivity in 'Manzanillo' under the experimental conditions (Fig. $1 \mathrm{~A}$ and $\mathrm{B})$.

Pollen germination increased rapidly in all treatments from day 2 to day 4 in 2016. The increase was slight thereafter. On the contrary, in 2017, pollen germination levels were maintained with erratic increases throughout the sampling period (Fig. 2A and B). In 2016, the percentage of germinated pollen grains was $\approx 20 \%$ in SP flowers and $\approx 30 \%$ in OP flowers. The data observed in $\mathrm{CP}$ flowers were more difficult to understand, with levels below those observed in SP and OP flowers 2 DAP, and significantly above those on the following dates (Fig. 2A). In 2017, 'Sevillano' pollen produced the
Table 4. Analyses of variance of fruit weight at harvest and its components in monovarietal and multivarietal 'Manzanillo' olive orchards in response to pollination treatments in season 2017. Nested design with orchard type as the first factor and pollination treatment as the second factor. Four trees as replicates in each treatment.

\begin{tabular}{|c|c|c|c|c|c|}
\hline $\begin{array}{l}\text { Orchard } \\
\text { type }\end{array}$ & $\begin{array}{l}\text { Pollination } \\
\text { treatment }^{z}\end{array}$ & Fruit wt $(g)^{y}$ & Pulp wt (g) & Pit wt (g) & Pulp/pit (ratio) \\
\hline \multirow[t]{3}{*}{ Monovarietal } & SP & $3.69 \mathrm{a}^{\mathrm{x}}$ & $2.85 \mathrm{~b}$ & $0.76 \mathrm{a}$ & $3.75 \mathrm{~b}$ \\
\hline & $\mathrm{OP}$ & $3.89 \mathrm{a}$ & $3.11 \mathrm{ab}$ & $0.79 \mathrm{a}$ & $3.93 \mathrm{a}$ \\
\hline & $\mathrm{XB}$ & $3.98 \mathrm{a}$ & $3.21 \mathrm{a}$ & $0.78 \mathrm{a}$ & $4.11 \mathrm{a}$ \\
\hline \multirow[t]{4}{*}{ Multivarietal } & SP & $2.95 \mathrm{a}$ & $2.18 \mathrm{~b}$ & $0.73 \mathrm{a}$ & $2.98 \mathrm{~b}$ \\
\hline & OP & $3.13 \mathrm{a}$ & $2.52 \mathrm{a}$ & $0.66 \mathrm{a}$ & $3.81 \mathrm{a}$ \\
\hline & $\mathrm{XB}$ & $3.37 \mathrm{a}$ & $2.63 \mathrm{a}$ & $0.74 \mathrm{a}$ & $3.55 \mathrm{a}$ \\
\hline & $\mathrm{XS}$ & $3.18 \mathrm{a}$ & $2.48 \mathrm{a}$ & $0.71 \mathrm{a}$ & $3.49 \mathrm{a}$ \\
\hline
\end{tabular}

${ }_{\mathrm{z}}^{\mathrm{z} P}=$ self-pollination; $\mathrm{OP}=$ open-pollination; $\mathrm{XB}=$ cross-pollination with 'Barouni' pollen; $\mathrm{XS}=$ cross-pollination with 'Sevillano' pollen.

${ }^{\mathrm{y}} \mathrm{lg}=0.0353 \mathrm{oz}$.

'Values followed by the same letter in each column are not significantly different at $P \leq 0.05$ using Tukey's Studentized range test.

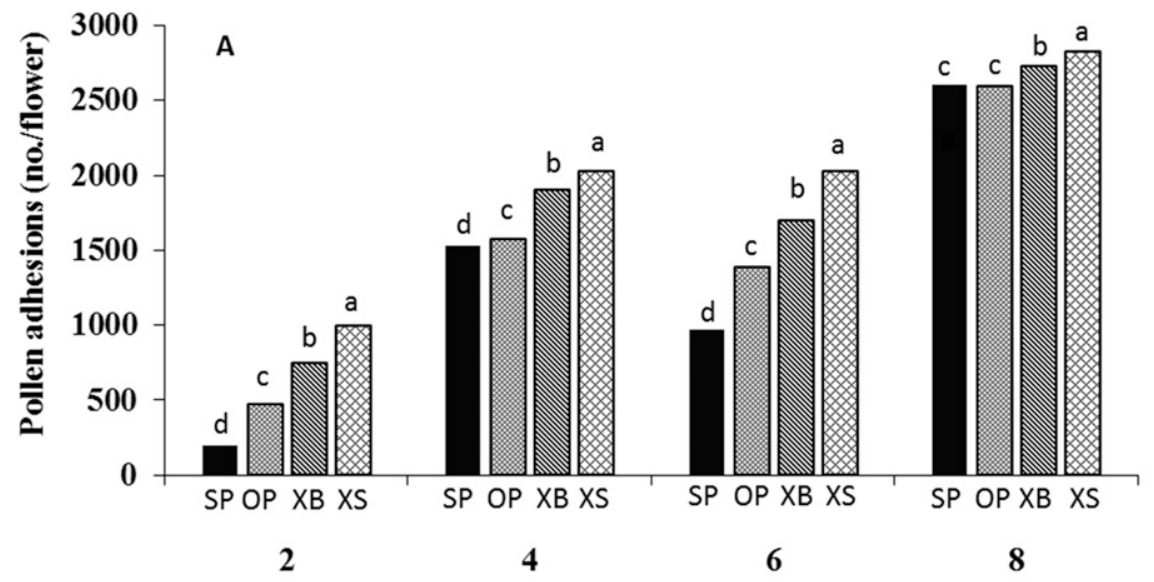

Days after pollination

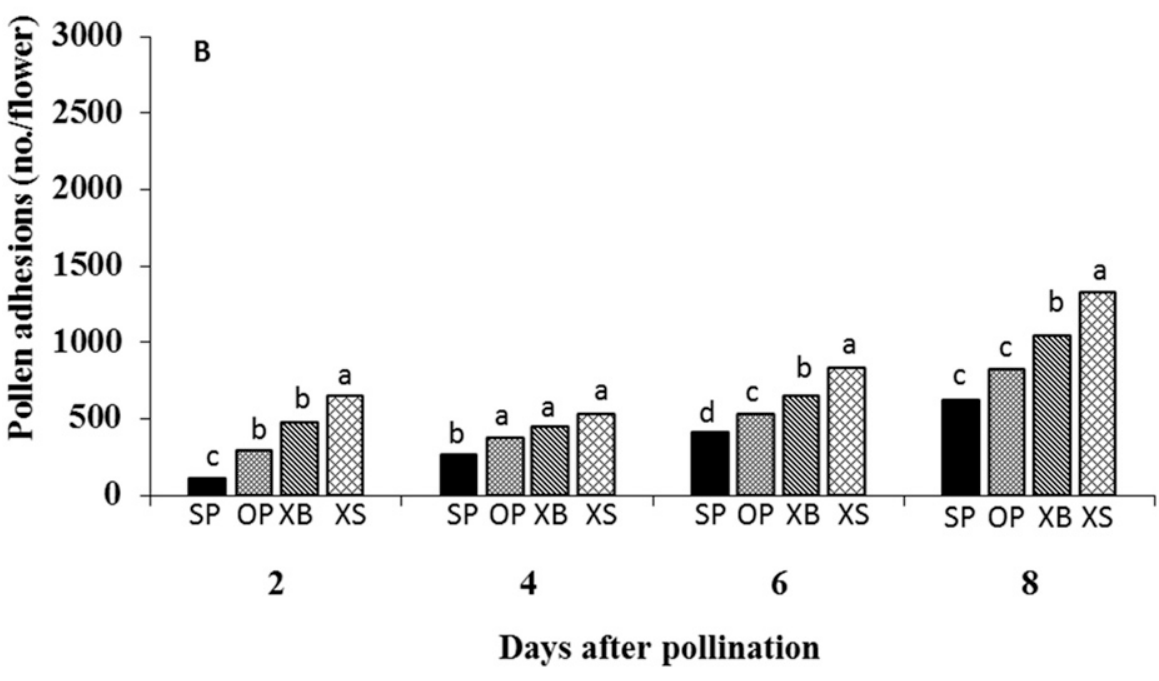

Fig. 1. Pollen adhesion in 2016 (A) and 2017 (B) in 'Manzanillo' olive trees under different pollination treatments $(S P=$ self-pollination; $O P=$ open-pollination; $\mathrm{XB}=$ cross pollination with 'Barouni' pollen; $\mathrm{XS}=$ cross-pollination with 'Sevillano' pollen). Values followed by the same letter on each day are not significantly different at $P \leq 0.05$ using Tukey's Studentized range test. 
highest germination at $4 \mathrm{DAP}$ and the lowest percentage $2 \mathrm{~d}$ later (6 DAP) (Fig. 2B). Nonetheless, except in very young flowers, the levels of pollen germination were high in 2017.

The dynamic of pollen tubes in the style varied greatly depending on pollination treatments. More flowers with more pollen tubes growing in the transmitting tissue of the style were seen in cross-pollinated flowers in both 2016 and 2017 (Supplemental Tables 1 and 2). The percentage of flowers showing abundant pollen tube growth in the style was much higher in $\mathrm{OP}$ and $\mathrm{CP}$ (XB and $\mathrm{XS}$ ) treatments than in SP, especially 6 and $8 \mathrm{DAP}$. In addition, it was common to see 5 to 25 pollen tubes per flower, or even more in the style of $\mathrm{OP}$ and CP flowers, whereas this situation rarely occurred under SP, where most flowers showed no pollen tubes in the style due to their early arrest in the stigma soon after germination (Fig. 3A and B). As expected, the number of pollen tubes observed in the transmitting tissue of the style was higher in older than in younger flowers (Supplemental Tables 1 and 2 ).

Because of the differential pollen tube growth, fertilization levels were higher in samples of OP and CP flowers than in SP flowers. Fertilization levels measured 8 DAP were significantly different among pollination treatments in both 2016 and 2017. In the former season, fertilization levels were higher for OP and CP (XB and XS) than for SP on each sampling date. Fertilization also occurred sooner in these treatments $(4$ DAP). Fertilization was rarely observed in SP flowers, even in old flowers. In 2016, more than half of the sampled flowers were fertilized under OP (55\% at $8 \mathrm{DAP})$, whereas the levels were lower for $\mathrm{CP}$ (XB and $\mathrm{XS}$ ), where $30 \%$ and $20 \%$, respectively, of the flowers showed ovules penetrated by a pollen tube. Only $5 \%$ of the flowers were fertilized under SP. In contrast, in 2017, CP flowers showed the highest levels of fertilization $(45 \%$ for XB and $25 \%$ for XS), whereas OP hardly reached $15 \% 6$ DAP. SP showed $10 \%$ of the flowers fertilized on the same date (Supplemental Tables 3 and 4).

Blooming PERIOD. 'Manzanillo' and 'Barouni' flowering periods coincided in both seasons. On the

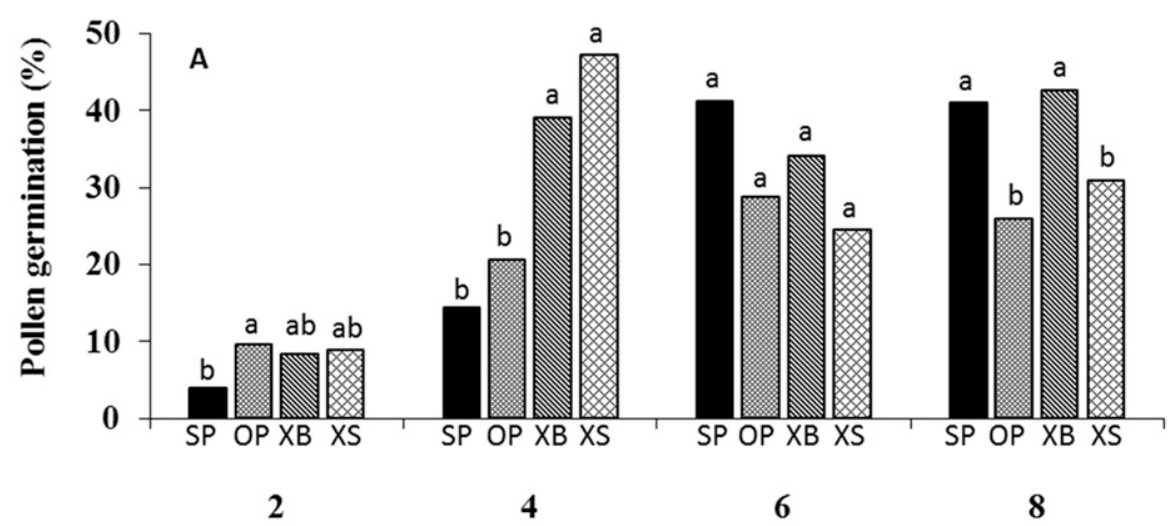

Days after pollination

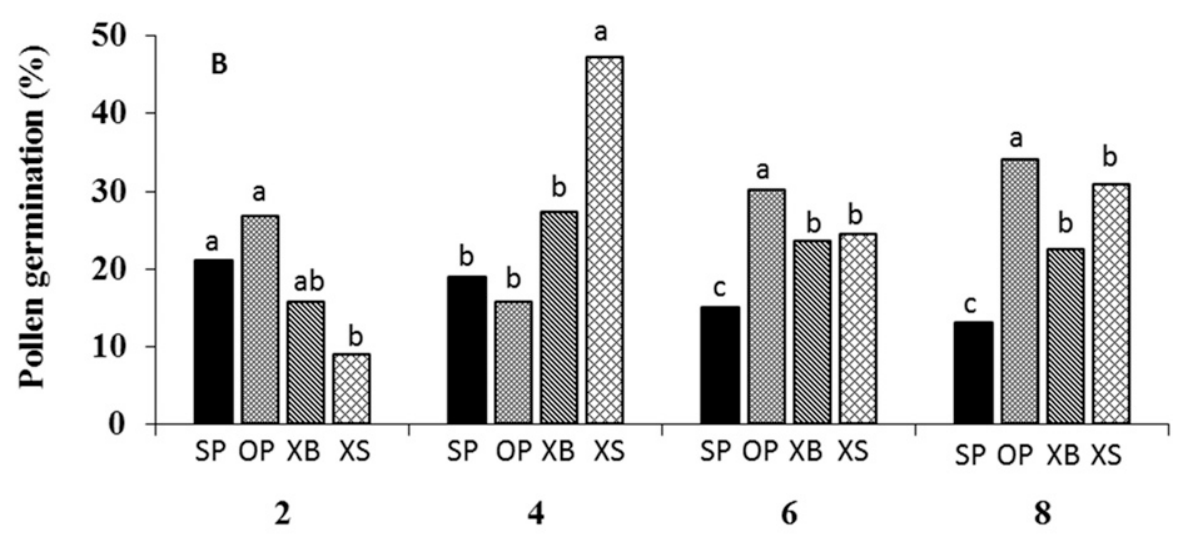

Days after pollination

Fig. 2. Pollen germination in 2016 (A) and 2017 (B) in 'Manzanillo' olive trees under different pollination treatments $(S P=$ self-pollination; $\mathrm{OP}=$ openpollination; $\mathrm{XB}=$ cross-pollination with 'Barouni' pollen; $\mathrm{XS}=$ cross pollination with 'Sevillano' pollen). Values followed by the same letter on each day are not significantly different at $P \leq 0.05$ using Tukey's Studentized range test.

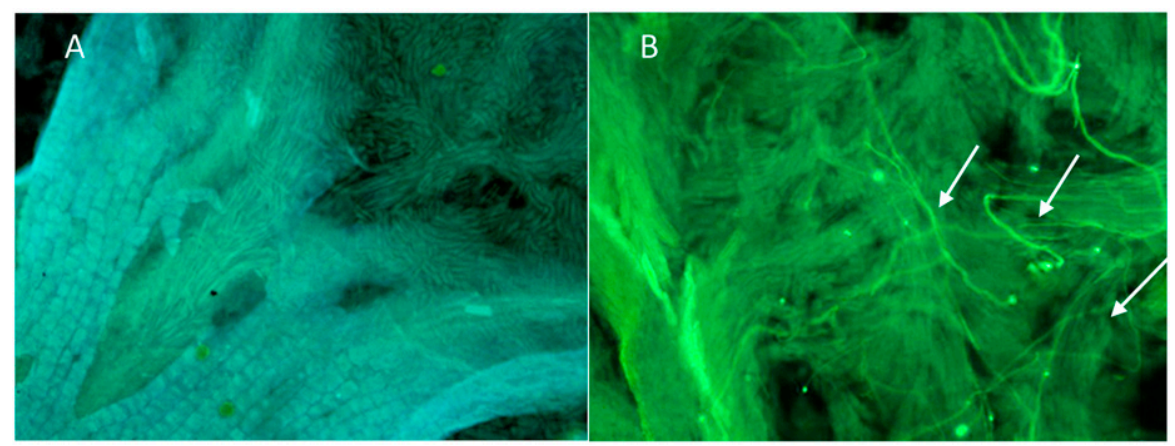

Fig. 3. Pollen tube growth in the style of self- (A) and cross-pollinated by 'Barouni' (XB) 'Manzanillo' olive flowers, $6 \mathrm{~d}$ after pollination. Note lack of pollen tubes in (A), whereas several pollen tubes (arrows) can be seen growing in the style of cross-pollinated flowers (B). Flowers observed under fluorescence microscopy $(\times 40)$ after squashing the pistil.

contrary, 'Sevillano' trees bloomed a little later, showing a shorter overlap with 'Manzanillo' bloom. In 'Manzanillo' and 'Barouni', the beginning of flowering began on 14 Mar., whereas full bloom started on 19 Mar. and finished 1 week later on 26 Mar. The end of flowering took place on 29 Mar. In contrast, in 2017, the onset of flowering began $5 \mathrm{~d}$ later than in 2016 and finished on 5 Apr. 'Sevillano' trees showed a delay of 1 week 
for each phenological stage of flowering in both years (Fig. 4).

\section{Discussion}

Our results show that 'Manzanillo' olive is highly SI because SP treatment consistently led to the lowest fruit set in both orchards and seasons. ISI values in both years and situations confirm a strong selfincompatibility system operating in 'Manzanillo' (Table 2). Fully SI behavior of 'Manzanillo' has been previously reported under similar environmental conditions in Mexico (Navarro-Ainza and López-Carvajal, 2013), California (Cuevas and Polito, 1997), and Arizona (Ayerza and Coates, 2004). The present results are in disagreement with those that suggest only partial SI in 'Manzanillo' and endorse solid, monovarietal orchards for this variety (FernándezEscobar and Rallo, 1981). Fruit set after self-pollination was extremely low and call in both seasons and orchards for orchard design including pollinizers in the correct number and position. A maximum distance of 30 to $40 \mathrm{~m}$ for pollinizers in 'Manzanillo' orchards has been previously suggested (Griggs et al., 1975; Lavee and Datt, 1978).

The mechanism of SI in olive is characterized by the limited capacity of its own pollen to penetrate beyond the first layers of stigma cells and by the inability to grow in its own style (Bradley and Griggs, 1963; Cuevas and Polito, 1997). This rejection often leads to a severe reduction in the percentage of self-fertilized flowers (Shemer et al., 2014; Vuletin-Selak et al., 2014). Our pollen-pistil interaction analyses reconfirm SI response of 'Manzanillo' and highlight self-pollen failure to achieve fertilization. Although pollen adhesion, and occasionally germination, under SP were also lower, they did not prove to be limiting factors. Differences in the pollination procedure (shaking vs. hand pollination) might explain the results observed on pollen adhesion.

Although SI response is mostly dependent on genotype, the relevance of the response varies according to the sources of $\mathrm{CP}$ available. In this regard, OP in the monovarietal orchard matched SP response, whereas, in contrast, OP in the multivarietal orchard attained the highest fruit set, even above levels found under $\mathrm{CP}$
(XB and XS). Similar trends were observed in 2016 and 2017: OP failed to increase fruit set with respect to SP in the monovarietal orchard, whereas it was the most favorable treatment in the multivarietal orchards. This opposite response to OP in terms of fruit set confirmed SI in 'Manzanillo' and the necessity of planting pollinizers for this olive (Lavee and Datt, 1978). The insufficient yield in response to $\mathrm{OP}$ in the monovarietal orchard also confirmed the limited wind diffusion of olive pollen and the dependence on $\mathrm{CP}$ from pollinizers in nontraditional countries such as Mexico.

If 'Manzanillo' behaves as a fully self-incompatible variety, a pollination design including a suitable pollinizer in the right number and place becomes critical. The success of a pollinizer in an orchard is ascertained by the productive response offered by the main variety in terms of fruit set (Seifi et al., 2012). Our results suggest a preference for 'Barouni' as pollinizer for Manzanillo instead 'Sevillano', which was previously reported as an excellent pollinizer for 'Manzanillo' in California (Cuevas and Polito, 1997). This preference for 'Barouni' as pollinizer is also based on the larger overlap for the former with the blooming period of 'Manzanillo' observed in both seasons (Fig. 4). This coincides with previous reports in Mexico (Navarro-Ainza et al., 2010) and Australia (Guerin and Sedgley, 2007), although the opposite occurs in Spain (Barranco et al., 1994). On the other hand, pollination with 'Barouni' pollen also yielded higher fruit set than 'Sevillano' pollen, which confirms it as a good pollinizer for 'Manzanillo' (Fichtner, 2012; Lavee and Datt, 1978; Navarro-Ainza and López-Carvajal, 2013; NavarroAinza et al., 2010). In fact, 'Sevillano' did not increase fruit set significantly the second season, perhaps because setting was lower for all treatments that season.

In addition, 'Barouni' is less alternating than 'Sevillano' (Sibbett et al., 1994), which is an important criterion for selecting a pollinizer. $\mathrm{Fi}^{-}$ nally, a surprising positive effect of $\mathrm{CP}$ was noted in the increase in fruit weight and pulp-to-pit ratio, and again the positive effect was higher for 'Barouni' than for 'Sevillano'. An increase in fruit weight (despite higher crop load) under CP was previously reported in certain olive varieties (Cuevas and Oller, 2002; Farinelli et al., 2012; Sánchez-Estrada and Cuevas, 2018) and explained by a higher rate of seed abortion and/or lighter seeds under SP, although seed characteristics have not been evaluated in this study.

\section{Conclusions}

'Manzanillo' is a highly selfincompatible variety that requires CP. Both 'Barouni' and 'Sevillano' are compatible with 'Manzanillo'. 'Barouni' presented a longer blooming overlap than 'Sevillano' with 'Manzanillo' flowering period, was able to fertilize a higher percentage of 'Manzanillo' flowers, produced slightly higher yield and fathered heavier fruit. Although the results in terms of induced fruit set were similar, we suggest 'Barouni' as a better choice because their bloom periods

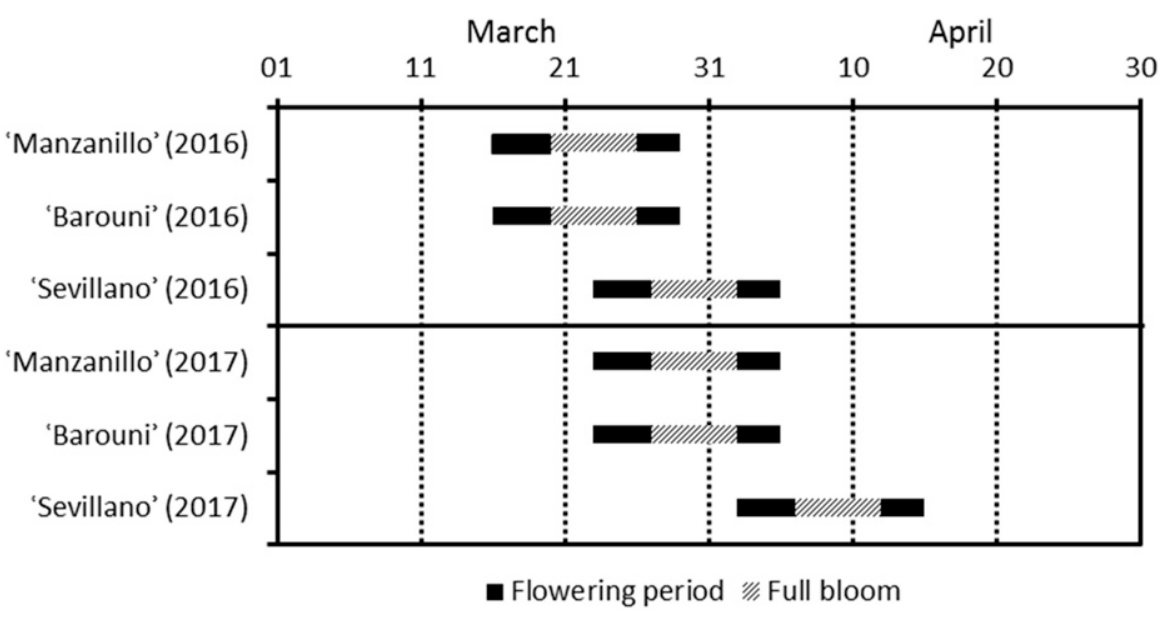

Fig. 4. Time of flowering of olive varieties Manzanillo, Barouni, and Sevillano (average of five trees) in Caborca, Sonora, Mexico (seasons 2016 and 2017). 
overlap extensively in both seasons. We strongly recommend including pollinizers in the design of 'Manzanillo' orchards given the risk of pollination deficits in single varietal gardens in nontraditional olive countries.

\section{Literature cited}

Alcalá, A.R. and D. Barranco. 1992. Prediction of flowering time in olive for the Cordoba olive collection. HortScience 27:1205-1207.

Androulakis, I.I. and M.H. Loupassaki. 1990. Studies on self-fertility of some olive cultivars in the area of Crete. Acta Hort. 286:159-162.

Ayerza, R. and W. Coates. 2004. Supplemental pollination - increasing olive (Olea europaea) yields in hot, arid environments. Expt. Agr. 40:481-491.

Barranco, D., G. Milona, and L. Rallo. 1994. Épocas de floración de cultivares de olivo en Córdoba. Investigación Agraria Producción y Protección Vegetales 9:213-220.

Bradley, M.V. and W.H. Griggs. 1963. Morphological evidence of incompatibility in Olea europea. Phytomorphology 13:141-156.

Cuevas, J., A.J. Díaz-Hermoso, D. Galián, J.J. Hueso, V. Pinillos, M. Prieto, D. Sola, and V.S. Polito. 2001. Response to cross-pollination and choice of pollinisers for the olive cultivars (Olea europaea L.) 'Manzanilla de Sevilla', 'Hojiblanca' and 'Picual'. Olivae 85:26-32.

Cuevas, J. and R. Oller. 2002. Olive seed set and its impact on seed and fruit weight. Acta Hort. 586:485-488.

Cuevas, J. and V.S. Polito. 1997. Compatibility relationships in 'Manzanillo' olive. HortScience 32:1056-1058.

Cuevas, J., L. Rallo, and H.F. Rapoport. 1994. Crop load effects on floral quality in olive. Scientia Hort. 59:123-130.

Cuevas, J. and V. Pinillos. 2006. Polinización artificial en olivo recolección. Agricultura $75: 418-424$

Dimassi, K., I. Therios, and A. Balatsos. 1999. The blooming period and selffruitfulness in twelve Greek and three foreign olive cultivars. Acta Hort. 474: 275-278.

Farinelli, D., P. Pierantozzi, and A.M. Palese. 2012. Pollenizer and cultivar influence seed number and fruit characteristics in Olea europaea L. HortScience 47:1430-1437.
Fernández-Escobar, R. and L. Rallo. 1981. Influencia de la polinización cruzada en el cuajado de frutos de cultivares de olivo (Olea europaea L.). Inf. Téc. Econ. Agrar. 45:51-58.

Fichtner, E.J. 2012. Olive bloom and pollination. Olive Notes. Univ. California Agr. Natural Resources Bul. 9(2). 25 Oct. 2018. <https://ucanr.edu/ datastoreFiles/832-33.pdf $>$.

Griggs, W., H. Hartmann, M.V. Bradley, B.T. Iwakiri, and J. Whisler. 1975. Olive pollination in California. Univ. California, California Agr. Expt. Sta. Bul. 869.

Guerin, J. and M. Sedgley. 2007. Crosspollination in olive cultivars. Rural Ind. Res. Dev. Corp. Austral. Austral. Govt. Barton, Canberra, Austral. p. 1-43.

Heslop-Harrison, J. and Y. Heslop-Harrison. 1970. Evaluation of pollen viability by enzymatically induced fluorescence intracellular hydrolysis of fluorescein diacetate. Stain Technol. 45:15-20.

Lavee, S. and Z. Datt. 1978. The necessity of cross-pollination for fruit set of 'Manzanillo' olives. J. Hort. Sci. 53:261-266.

Lavee, S., J. Taryan, J. Levin, and A. Haskal. 2002. The significance of crosspollination for various olive cultivars under irrigated intensive growing conditions. Olivae 91:25-36.

Martin, F.W. 1958. Staining and o serving pollen tubes in the style by means of fluorescence. Stain Technol. 34:125-128.

Navarro-Ainza, J.A.C., A. Fimbres-Fontes, A. López-Carbajal, and F. Robles-Contreras. 2010. Demonstration plots yield established with pollination and irrigation in commercial olive orchards (Olea europaea L.). Rev. Chapingo Ser. Zonas Áridas 9:61-66.

Navarro-Ainza, J.A.C. and A. LópezCarvajal. 2013. Cuajado de frutos y partenocarpia en olivo 'Manzanillo' con polinización cruzada. Agron. Mesoam. 24:393-400.

Pinillos, V. and J. Cuevas. 2008. Standardization of the fluorochromatic reaction test to assess pollen viability. Biotech. Histochem. 83:15-21.

Pinillos, V. and J. Cuevas. 2009. Openpollination provides sufficient levels of cross-pollen in Spanish monovarietal olive orchards. HortScience 44:499-502.

Rapoport, H.F. and L. Rallo. 1991. Postanthesis flower and fruit abscission in 'Manzanillo' olive. J. Amer. Soc. Hort. Sci. 11:720-723.
Rejano, L., A. Montaño, F.J. Casado, A.H. Sánchez, and A. de Castro. 2010. Table olives: Varieties and variations, p. 515. In: V.R. Preedy and R.R. Watson (eds.). Olives and olive oil in health and disease prevention. Elsevier, Amsterdam, The Netherlands.

Ruíz-Corral, J.A., G. Medina-García, J. Grajeda-Grajeda, M.M. Silva-Serna, and G. Díaz-Padilla. 2005. Estadísticas climatológicas básicas del Estado de Sonora (periodo 1961-2003). Libro Técnico No. 1. Instituto Nacional Investigaciones Forestales Agrarias y PecuariasCampo Investigación Regional NoroesteSecretaría Agricultura, Ganadería, Desarrollo Rural, Pesca y Alimentación. Cd. Obregón, Sonora, México.

Sánchez-Estrada, A. and J. Cuevas. 2018. 'Arbequina' olive is self-incompatible. Scientia Hort. 230:50-55.

Seifi, E., J. Guerin, B. Kaiser, and M. Sedgley. 2011. Sexual compatibility and floral biology of some olive cultivars. N. Z. J. Crop Hort. Sci. 39:141-151.

Seifi, E., J. Guerin, B. Kaiser, and M. Sedgley. 2012. Sexual compatibility of the olive cultivar 'Kalamata' assessed by paternity analysis. Span. J. Agr. Res. 10:731-740.

Shemer, A., I. Biton, Y. Many, Y. Vaknin, S. Lavee, B. Avidan, and G. Ben-Ari. 2014. The olive cultivar 'Picual' is on optimal donor for 'Barnea'. Scientia Hort. 172:278-284.

Sibbett, G.S., L. Ferguson, and G.C. Martin. 1994. Olive production manual. Univ. California, Agr. Natural Resources, Oakland.

Sibbett, G.S., M. Freeman, L. Ferguson, and V.S. Polito. 1992. Effect of topically applied 'Sevillano' pollen on normalseeded and parthenocarpic "shotberry" fruit set of 'Manzanillo' olive. HortTechnology 2:228-230.

Vuletin-Selak, G., S. Perica, S. Goreta Ban, and M. Poljak. 2014. The effect of temperature and genotype on pollen performance in olive (Olea europaea L.). Scientia Hort. 156:38-46.

Wu, S.B., G. Collins, and M. Sedgley. 2002. Sexual compatibility within and between olive cultivars. J. Hort. Sci. Biotechnol. 77:665-673.

Zapata, T.R. and M.T.K. Arroyo. 1978. Plant reproductive ecology of a secondary deciduous tropical forest. Biotropica 10:221-230. 


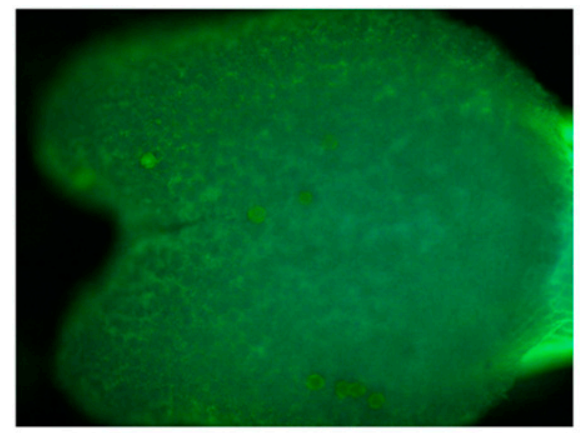

0 pollen tube

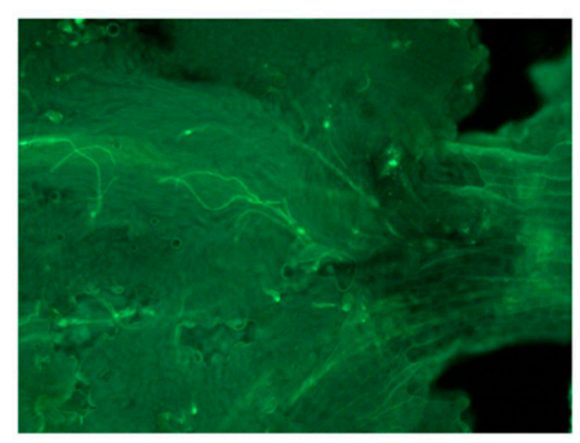

5-25 pollen tubes

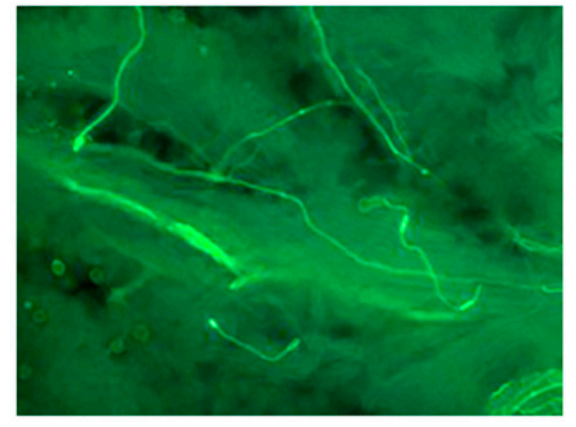

1-4 pollen tubes

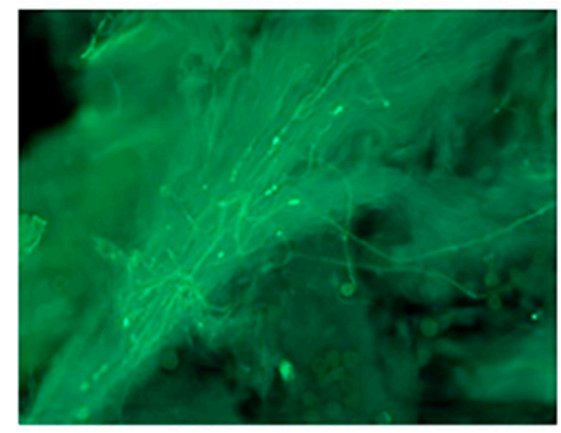

$>25$ pollen tubes

Supplemental Fig. 1. Categories used to define the amount of pollen tubes growing in the style of 'Manzanillo' olive flowers: null (no pollen tubes), scarce (1-4 tubes), moderate (5-25 tubes), or massive (more than 25 tubes).

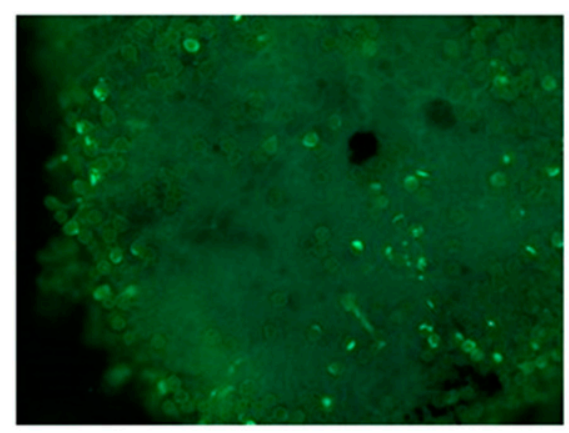

Pollen Adhesion and Germination

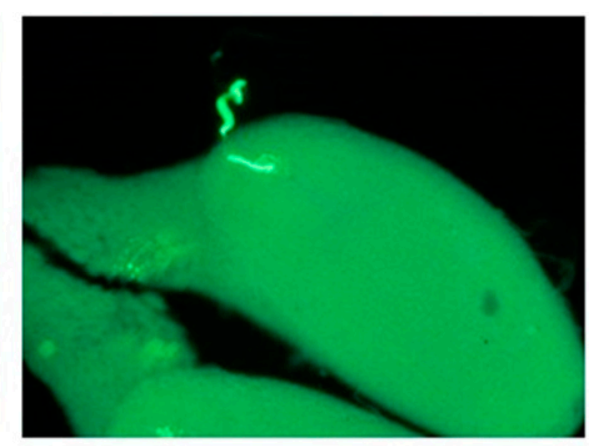

Fertilization

Supplemental Fig. 2. Procedures to assess pollen adhesion/germination and flower fertilization in olive flowers. Ovules were dissected from the ovary for observation. 


\section{Research Reports}

Supplemental Table 1. Pollen tube growth dynamic in the style of self-, openand cross-pollinated flowers of 'Manzanillo' olive trees in 2016.

Pollen tubes

\begin{tabular}{lcrrrr} 
& & \multicolumn{4}{c}{ observed in the style $(\mathbf{\%})^{\mathbf{y}}$} \\
\cline { 3 - 6 } Pollination treatment $^{\mathbf{z}}$ & \multicolumn{1}{c}{$\mathbf{0}$} & $\mathbf{1 - 5}$ & $\mathbf{5 - 2 5}$ & $\mathbf{2 5}$ \\
\hline SP & Days after pollination & 100 & 0 & 0 & 0 \\
& 2 & 74 & 26 & 0 & 0 \\
& 4 & 33 & 28 & 39 & 0 \\
OP & 6 & 8 & 71 & 14 & 7 \\
& 8 & 94 & 6 & 0 & 0 \\
& 2 & 40 & 40 & 15 & 5 \\
XB & 4 & 40 & 30 & 25 & 5 \\
& 6 & 0 & 25 & 65 & 10 \\
& 8 & 100 & 0 & 0 & 0 \\
& 2 & 25 & 19 & 13 & 43 \\
XS & 4 & 17 & 65 & 12 & 6 \\
& 6 & 0 & 73 & 7 & 20 \\
& 8 & 95 & 5 & 0 & 0 \\
& 2 & 10 & 30 & 10 & 50 \\
& 4 & 17 & 33 & 28 & 22 \\
& 6 & 0 & 66 & 0 & 34 \\
\hline
\end{tabular}

${ }^{\mathrm{z}} \mathrm{SP}=$ self pollination; $\mathrm{OP}=$ open-pollination; $\mathrm{XB}=$ cross-pollination with 'Barouni' pollen; $\mathrm{XS}=$ cross-pollination with 'Sevillano' pollen.

${ }_{2} 0$ flowers per date and treatment (occasionally some flowers missing).

Supplemental Table 2. Pollen tube growth dynamic in the style of self-, open-, and cross-pollinated flowers of 'Manzanillo' olive trees in 2017.

Pollen observed in the style $(\%)^{y}$

\begin{tabular}{lccccr} 
Pollination treatment $^{\mathbf{z}}$ & Days after pollination & $\mathbf{0}$ & $\mathbf{1 - 5}$ & $\mathbf{5 - 2 5}$ & $\mathbf{>} \mathbf{2 5}$ \\
\hline SP & 2 & 80 & 20 & 0 & 0 \\
& 4 & 70 & 30 & 0 & 0 \\
& 6 & 70 & 30 & 0 & 0 \\
OP & 8 & 75 & 20 & 5 & 0 \\
& 2 & 65 & 35 & 0 & 0 \\
& 4 & 45 & 55 & 0 & 0 \\
XB & 6 & 20 & 80 & 0 & 0 \\
& 8 & 0 & 90 & 5 & 5 \\
& 2 & 80 & 20 & 0 & 0 \\
& 4 & 40 & 35 & 5 & 20 \\
XS & 6 & 20 & 80 & 0 & 0 \\
& 8 & 30 & 40 & 10 & 20 \\
& 2 & 80 & 20 & 0 & 0 \\
& 4 & 30 & 70 & 0 & 0 \\
& 6 & 30 & 70 & 0 & 0 \\
& 8 & 25 & 75 & 0 & 0 \\
\hline
\end{tabular}

${ }^{\mathrm{z}} \mathrm{SP}=$ self-pollination; $\mathrm{OP}=$ open-pollination; $\mathrm{XB}$ = cross-pollination with 'Barouni' pollen; $\mathrm{XS}=$ cross-pollination with 'Sevillano' pollen.

$\mathrm{y}_{2} 2$ flowers per date and treatment (occasionally some flowers missing). 
Supplemental Table 3. Chi-square distribution table of number of fertilized flowers on each day sampled of self-, open-, and cross-pollinated flowers of 'Manzanillo' olive trees in 2016. Values are of the observed flowers, between parenthesis expected values.

\begin{tabular}{llccr}
\hline & \multicolumn{4}{c}{ Number of flowers fertilized [observed (expected) ] } \\
\cline { 2 - 5 } & \multicolumn{4}{c}{ Days after pollination } \\
\cline { 2 - 5 } Pollination treatment & $\mathbf{2}$ & $\mathbf{4}$ & $\mathbf{6}$ & $\mathbf{8}$ \\
\hline SP & $0(0.54)$ & $0(3.30)$ & $1(3.16)$ & $0(4.52)$ \\
OP & $0(0.54)$ & $4(3.47)$ & $3(3.51)$ & $11(6.46)$ \\
XB & $1(0.37)$ & $5(3.47)$ & $4(2.98)$ & $6(6.13)$ \\
XS & $1(0.54)$ & $3(1.73)$ & $5(3.33)$ & $4(3.87)$ \\
\hline${ }^{2}$ SP = self-pollination; OP = open-pollination; XB = cross-pollination with 'Barouni' pollen; XS = cross-pollination \\
with 'Sevillano' pollen. \\
y20 flowers per date and treatment.
\end{tabular}

Supplementary Table 4. Chi-square distribution table of number of fertilized flowers of self-, open-, and cross-pollinated flowers of 'Manzanillo' olive trees in 2017. Values are of the observed flowers, and those in parentheses are expected values.

\begin{tabular}{|c|c|c|c|c|}
\hline \multirow[b]{3}{*}{ Pollination treatment $^{\mathrm{z}}$} & \multicolumn{4}{|c|}{ Number of flowers fertilized [observed (expected)] } \\
\hline & \multicolumn{4}{|c|}{ Days after pollination } \\
\hline & 2 & 4 & 6 & 8 \\
\hline SP & $0(0.5)$ & $1(1.0)$ & $2(0.38)$ & $1(3.5)$ \\
\hline $\mathrm{OP}$ & $0(0.5)$ & $1(1.0)$ & $3(7.00)$ & $3(3.5)$ \\
\hline $\mathrm{XB}$ & $2(0.5)$ & $2(1.0)$ & $9(5.23)$ & $5(3.5)$ \\
\hline XS & $0(0.5)$ & $1(1.0)$ & $4(5.37)$ & $5(3.5)$ \\
\hline
\end{tabular}

